\title{
APPLICATION OF HIGH-TECH AGRICULTURE BY HOUSEHOLDS IN THE RED RIVER DELTA OF VIETNAM
}

\author{
The Kien NGUYEN \\ VNU University of Economics and Business, Center for Socio-Economic Analysis \\ and Databases (CSEAD), Hanoi, Vietnam, e-mail: nguyenthekien@vnu.edu.vn
}

\author{
Xuan Nam VU* \\ Thai Nguyen University, University of Information and Communication Technology, \\ Department of Economic Information System, Thainguyen, Vietnam, e-mail: vxnam@ictu.edu.vn
}

Quang Van NGO

Hanoi University of Industry, Faculty of Business Management, Hanoi, Vietnam, e-mail: quangnv@ haui.edu.vn

\section{Thanh Ha PHAM}

VNU University of Social and Humanities, Phiosophy of department, Hanoi, Vietnam, e-mail: hapham@ vnu.edu.vn

\author{
Khanh Cuong LE
}

VNU University of Economics and Business, Hanoi, e-mail: cuonglk@ vnu.edu.vn

Thi Le NGUYEN

National Academy Of Public Administration, Department of Graduate Training Management, e-mail: Lent@ napa.vn

\begin{abstract}
Citation: Nguyen, T.K., Vu, X.N., Ngo, Q.V., Pham, T.H., Le, K.C., \& Nguyen, T.L. (2021). APPLICATION OF HIGH-TECH AGRICULTURE BY HOUSEHOLDS IN THE RED RIVER DELTA OF VIETNAM. GeoJournal of Tourism and Geosites, 39(4spl), 1415-1420. https://doi.org/10.30892/gtg.394spl12-785
\end{abstract}

\begin{abstract}
This study is conducted to model the factors that influence the decision to apply high technology in agricultural production (agricultural production) of farmers in the Red River Delta (RRD), Vietnam. Data used for the study are surveyed in fact 600 households participating in agricultural production in the RRD. The paper uses the Binary Logistic regression analysis method to identify the factors affecting the decision to apply high technology to agricultural production. The research results show that factors such as farm households' education, people's participation in social organizations, the impact of urbanization, capital and market availability all have positive effects extreme decision to apply technology of farmers. Based on the results of the study, the paper proposed policies to be focused on to enhance the application of high technology in agricultural production by farmers. The findings of this study demonstrate that people's application of high technology to agricultural production is improved by enhancing their production capacity.
\end{abstract}

Key words: High-tech agriculture, agricultural production, technology application, Red River Delta, Vietnam

$* * * * * *$

\section{INTRODUCTION}

From the new pressures of international economic integration and the impact of climate change, the need for the development of high-tech agriculture (HTA) is put at the forefront towards the goal of improving efficiency, breakthrough in productivity, and quality of products. HTA is an agriculture that applies new technologies to production including agricultural technology (ie production mechanization), automation, biotechnology, information technology, new materials and plants and animals with high productivity and quality, high efficiency per unit acreage and develop sustainably on the basis of ownership, at the same time, HTA can also protect the environment through reducing use of agrochemicals (Xo and Nhuong, 2006; Wolf and Terrell, 2016). The Covid -19 pandemic took place, once again affirming that agriculture is a safe platform for countries with agricultural advantages like Vietnam (Gregorioa and Ancog, 2020). Vietnam is considered an agricultural country with over $80 \%$ of the population in rural areas and about $74.6 \%$ of the population working in agriculture. In recent years, growth and development of the agriculture in Vietnam, according to some studies, is still mainly based on the use of human resources, natural resources and input materials (Tri, 2021).

At the same time, the value of agricultural products is still low because most of them are still in raw form and their quality is not high, their competitiveness is low, they have not really used effectively and brought into play all resources. The RRD is a large land located around the lower Red River in northern Vietnam. The land of the region is very suitable for intensive wet rice cultivation, crops and short-term industrial crops. The region has the second largest growing area of food crops in the country with an area of 1242.9 thousand hectares. Most of the provinces in the RRD (Ha Nam, Nam Dinh, Thai Binh, Hai Duong, Ninh Binh, etc.) lead the country in land consolidation, land accumulation to form large

\footnotetext{
${ }^{*}$ Corresponding author
} 
fields, bringing mechanization into production to improve labor productivity, thereby forming concentrated production areas, such as: The carrot growing area in Gia Binh is 700 ha wide and the potato growing area in Que Vo is nearly 1,500 ha (Bac Ninh) ; the carrot growing area in Cam Giang (Hai Duong) is over 500 ha wide, the onion and garlic growing area in Kinh Mon (Hai Duong) is over 3,000 ha; flowers and ornamental plants in Van Giang (Hung Yen) are over 250 hectares wide, etc. (Chinh, 2020). However, the process of applying high technology to agricultural production in the RRD is still slow, inconsistent and spontaneous (Dang et al., 2011; Luu et al., 2019). Therefore, this study selected the RRD region as a typical model for the study. The topic of high-tech application in agricultural production is also quite attractive to interested researchers (Biwas, 2010). Some recent empirical studies show that the level of access to high technology depends on many factors such as demographics, production conditions of farmers, policies, extension services, market (Li et al., 2019; Baffoe-Asare et al., 2013; Son and Thanh, 2014).

Many methods are applied to evaluate the factors affecting the decision to apply industrial technology, such as the Tobit regression method, which is used to evaluate socio-economic factors affecting the decision to apply public works high technology (CODAPEC) of farmers in central Ghana (Baffoe-Asare et al., 2013; Eneji et al., 2012; Thien and Hanh, 2019); structural modeling method (SEM) to determine the factors affecting the degree of agricultural mechanization in China ( $\mathrm{Li}$ et al., 2019); the regression and correlation analysis method is used to examine the relationship between the factors affecting the application of agricultural technology by smallholder farmers in Kakamega (Kinyangi, 2012); logistic regression method and factor analysis (EFA) are used to evaluate the factors affecting the decision to apply technical advances and the degree of application of technical advances to rice production of farmers in Hau Giang province (Son and Thanh, 2014). In this study, the authors choose the Binary Logistic Model to identify the factors that affect the farmers' decision to apply high technology in agricultural production.

Since the Binary Logistic Model is used to estimate the probability of an event, the feature of the model that the dependent variable has only two values of 0 and 1 is called a binary variable. When the dependent variable is in binary form, it cannot be analyzed with conventional regression because it will violate assumptions, most clearly when the dependent variable has only two expressions, it is not suitable to assume that the remainder has the normal distribution, but instead it will have the binomial distribution, which would statistically invalidate the tests in the normal regression (Son and Thanh, 2014; Loc, 2019; Phuong and Hien, 2014). This study aims to analyze the factors that affect the farmers' decision to apply high technology to agricultural production. The main objectives that need to be addressed in the article are: (i) Building a model of factors that affect decisions on high technology application and determining analytical methods; (ii) Analyze the results from the model, discuss and draw limitations of the research, and at the same time give the next research direction; (iii) Proposing a number of recommendations to promote the agricultural technology development of farmers in the RRD in particular and Vietnamese farmers in general.

\section{MATERIALS AND METHODS 1. Study Area}

The RRD region extends from latitude $21^{\circ} 34^{\prime} \mathrm{N}$ (Lap Thach district) to the alluvial area about $19^{\circ} 5^{\prime} \mathrm{N}$ (Kim Son district), from $105^{\circ} 17^{\prime} \mathrm{E}$ (Ba Vi district) to $107^{\circ} 7^{\prime} \mathrm{E}$ (Cat $\mathrm{Ba}$ Island). The RRD including 10 provinces and cities such as Vinh Phuc, Hanoi, Bac Ninh, Ha Nam, Hung Yen, Hai Duong, Hai Phong, Thai Binh, Nam Dinh, Ninh Binh. The whole region has an area of $20.973 \mathrm{~km}^{2}$, accounting for $7 \%$ of the total area of the country. The population density of the region is the highest in Vietnam (1064 people $/ \mathrm{km}^{2}$, population is 22 million). The area of agricultural land is about 760,000 ha, of which $70 \%$ is fertile alluvial soil, which has great value for agricultural production. Agricultural land occupies $51.2 \%$ of the area. Three

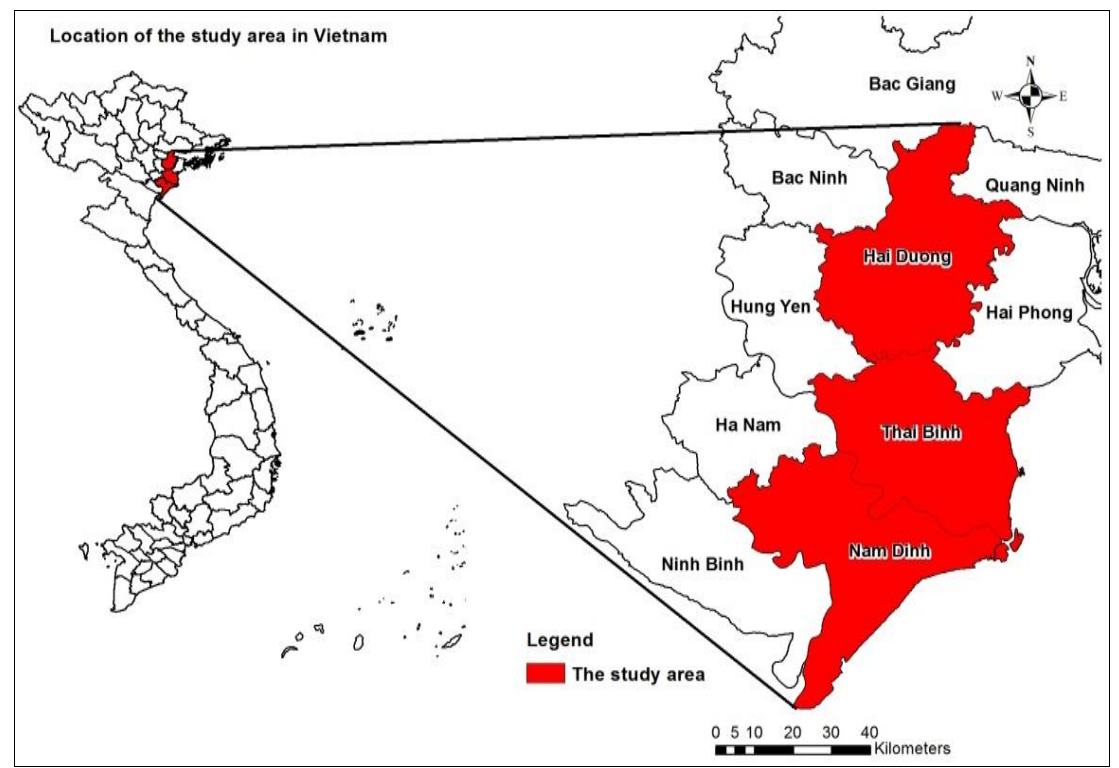

Figure 1. Location of three selected provinces in the RRD, Vietnam provinces including Nam Dinh, Thai Binh, Hai Duong are selected as study areas because they are the key agricultural areas in the RRD. Nam Dinh is a province located in the south of the Northern Delta (also known as the RRD). Nam Dinh province stretches from $19^{\circ} 54^{\prime} \mathrm{N}$ to $20^{\circ} 40^{\prime} \mathrm{N}$ and from $105^{\circ} 55^{\prime} \mathrm{E}$ to $106^{\circ} 45^{\prime} \mathrm{E}$. To the north, it borders Thai Binh province. To the south, it borders Ninh Binh province. The West borders Ha Nam province.

East sea bordering the east. (The administrative atlas of Vietnam, 2013). In 2020, The province's gross domestic product (GRDP) was estimated at 46,121 billion VND, up 5.5\% over the previous year. In which, the agriculture, forestry and fishery sector was 9,590 billion VND, up 3.99\%. Economic structure: The agriculture, forestry and fishery sector accounts for 22.46\%; industry and construction accounted for 39.48\%; service sector accounted for 34.93\%; product tax minus product subsidies accounted for $3.13 \%$ (namdinh.gov.vn). 
Thai Binh is a coastal province in the RRD. Thai Binh province has coordinates from $20^{\circ} 18^{\prime} \mathrm{N}$ to $20^{\circ} 44^{\prime} \mathrm{N}, 106^{\circ} 06^{\prime} \mathrm{E}$ to $106^{\circ} 39^{\prime} \mathrm{E}$. The North borders Hai Duong province, Hung Yen province and Hai Phong city. The West borders Ha Nam province. To the south, it borders Nam Dinh province. East sea bordering the east. (vi.wikipedia.org). Thai Binh is a coastal province in the RRD, with a natural area of $1,534.4 \mathrm{~km}^{2}$, a population of about 1.8 million people. Thai Binh is a coastal province in the RRD, with a natural area of $1,534.4 \mathrm{~km}^{2}$, a population of about 1.8 million people. 2020, Gross domestic product in the GRDP is estimated at 53,523 billion VND, an increase of over 3.2\% compared to 2019; in which the agriculture, forestry and fishery sector increased by $3.4 \%$. The per capita income of Thai Binh province in 2020 is estimated at 50.76 million VND/ person / year (thaibinh.gov.vn). Hai Duong stretches from $20^{\circ} 43^{\prime}$ to $21^{\circ} 14^{\prime}$ north latitude, $106^{\circ} 03^{\prime}$ to $106^{\circ} 38^{\prime}$ east longitude. The North borders Bac Giang province. The East borders Quang Ninh province and Hai Phong city. The West borders Bac Ninh province and Hung Yen province. To the south, it borders Thai Binh province. Hai Duong has an area of 1,662 $\mathrm{km}^{2}$. In 2020, Hai Duong is the 8th largest administrative unit in Vietnam in terms of population with $1,916,774$ people, the GRDP growth rate is $2.1 \%$. GRDP reached 134,700 billion VND (equivalent to 5.790 billion USD), GRDP per capita reached 69.8 million VND (equivalent to 3,020 USD) (vi.wikipedia.org).

\section{Basis for building research model}

Based on the conceptual framework of Kinyangi (2012); Wei et al. (2019); Kinyangi (2012); Bucci et al. (2019); Anh (2012); Baffoe-Asare et al. (2013); Son and Thanh (2014); and in combination with consulting experts and results of the trial investigation, the research selected Binary Logistic model with the following variables: $\operatorname{Ln}\left[\frac{P(Y=1)}{P(Y=0)}\right]=\beta_{0}+\beta_{1}$ NOE $+\beta_{2} \mathrm{EDU}+\beta_{3} \mathrm{PSO}+\beta_{4} \mathrm{CAP}+\beta_{5} \mathrm{EXP}+\beta_{6} \mathrm{URB}+\beta_{7} \mathrm{MAR}$

In which: $\mathrm{Y}$ is a binary variable, representing the application of high technology of a farmer to production and is measured by two values 1 and 0 ( 1 is a farmer with at least one high-tech model application, 0 is farm households that do not apply high technology or are called traditional agricultural households).

$\mathrm{P}(\mathrm{Y}=1)=\mathrm{P}_{0}$ is the probability of applying high technology;

$\mathrm{P}(\mathrm{Y}=0)=1-\mathrm{P}_{0}$ is the probability of not applying high technology;

$\operatorname{Ln} \frac{P O}{1-P 0}=\beta_{0}+\beta_{1} \mathrm{NOE}+\beta_{2} \mathrm{EDU}+\beta_{3} \mathrm{PSO}+\beta_{4} \mathrm{CAP}+\beta_{5} \mathrm{EXP}+\beta_{6} \mathrm{URB}+\beta_{7} \mathrm{MAR}$

Odds: $\mathrm{O}_{0}=\frac{\mathrm{PO}}{1-\mathrm{PO}}=\frac{P(\text { applying high technology })}{P(\text { not applying high technology })}$ Thus, the Binary Logistic regression function on factors affecting the decision to apply technology in agricultural production is as follows:

$$
\mathrm{Ln} \mathrm{O}_{0}=\beta_{0}+\beta_{1} \mathrm{NOE}+\beta_{2} \mathrm{EDU}+\beta_{3} \mathrm{PSO}+\beta_{4} \mathrm{CAP}+\beta_{5} \mathrm{EXP}+\beta_{6} \mathrm{URB}+\beta_{7} \mathrm{MAR}
$$

Table 1. Interpretation of the variables in the model (Source: Authors synthesized, 2020)

\begin{tabular}{|c|c|c|c|c|}
\hline & Variable & Interpretation & Source & Expectation \\
\hline & $\begin{array}{l}\text { Number of } \\
\text { employees (NOE) }\end{array}$ & $\begin{array}{l}\text { Total number of employees directly involved in } \\
\text { agricultural production in the household of a farmer. }\end{array}$ & $\begin{array}{l}\text { Li et al., 2019; Son and } \\
\text { Thanh, } 2014\end{array}$ & + \\
\hline & Education (EDU) & $\begin{array}{l}\text { Years of schooling that the head of the household has } \\
\text { studied up to the time of the study. }\end{array}$ & $\begin{array}{l}\text { Baffoe - Asare et al., 2013; } \\
\text { Bucci et al., } 2019\end{array}$ & + \\
\hline & $\begin{array}{l}\text { Participation in } \\
\text { a social organization (PSO) }\end{array}$ & $\begin{array}{l}1=\text { farmer participates in a social organization } \\
0=\text { farmer participates in any organization }\end{array}$ & Son and Thanh, 2014 & + \\
\hline Independent & $\begin{array}{l}\text { Capital } \\
\text { (CAP) }\end{array}$ & $\begin{array}{l}1=\text { farmer has a loan } \\
0=\text { farmer has no loan }\end{array}$ & $\begin{array}{l}\text { Baffoe-Asare et al., 2013; } \\
\text { Kinyangi, } 2012 .\end{array}$ & \\
\hline & Experience (EXP) & $\begin{array}{l}\text { Number of years the household head was participated } \\
\text { in agricultural production as of the study time }\end{array}$ & $\begin{array}{l}\text { Richard Baffoe - Asare et } \\
\text { al., } 2013\end{array}$ & + \\
\hline & Urbanization (URB) & $\begin{array}{l}\text { Farmers' assessment of the affected urbanization } \\
\text { process agricultural production activities }(1= \\
\text { completely unaffected; } \ldots ; 5=\text { completely affected })\end{array}$ & Anh, 2012 & + \\
\hline & Market (MAR) & $\begin{array}{l}\text { Farmers' assessment of market availability for } \\
\text { agricultural products }(1=\text { complete } \\
\text { do not affect; } \ldots ; 5=\text { refund full influence })\end{array}$ & Anh, 2012; Kinyangi, 2012 & + \\
\hline $\begin{array}{l}\text { Dependent } \\
\text { variable }\end{array}$ & $\begin{array}{l}\text { Decision on application } \\
\text { of high technology in } \\
\text { agricultural production (DAHT) }\end{array}$ & $\begin{array}{l}1=\text { applying high technology } \\
0=\text { not applying high technology }\end{array}$ & $\begin{array}{l}\text { Kinyangi, 2012; Son and } \\
\text { Thanh, } 2014\end{array}$ & \\
\hline
\end{tabular}

\section{Sampling method}

To ensure the science and representativeness of the primary data, the minimum sample size to achieve is calculated by the formula $\mathrm{N}>50+8 * \mathrm{~m}$ (m: number of independent variables) [24]. This study consists of 7 independent variables, so the minimum sample number will be $\mathrm{N}=50+8 * 7=106$ survey samples. However, in order to have accurate results, the topic has arranged to survey 600 questionnaires to ensure the number of questionnaires. The data collection includes the steps:

Step 1: Contacting the survey site to select the study area, consulting with local officials and experts to select the site. After consulting, the author selected survey locations in 3 highly representative provinces: Nam Dinh, Thai Binh, Hai Duong.

Step 2: Based on the results of document review, consult experts and local practices, research to build and complete the initial survey. After that, the authors group conducted a trial investigation of 50 questionnaires to check the suitability of the survey, and at the same time correct the survey. 
Step 3: After editing the survey questionnaire, the authors conduct an official survey with a sample size of 600 farmer households. The survey process will be conducted from May to July 2020.

After collecting and synthesizing the questionnaires, the study used SPSS 20 software to analyze the data. The specific analysis steps are as follows: Descriptive statistical analysis; Analysis of tests; Binary Logistic regression results discussed.

\section{RESULTS AND DISCUSSION}

\section{Descriptive statistics}

Based on the results collected from the survey, there are 32 unsatisfactory responses, 568 valid votes are collected, the results are presented in Table 2. Out of 568 interviewees, female farmers are more likely to respond than men, this could also indicate that more men are working in factories, companies, and institutions. more organizations than women; Women stay mainly at home, farming and taking care of the children.

The age group to participate in interviews is relatively equal, but the groups that respond the most are 20-29 and 4049 years old. The results indicate that experience, knowledge, competencies and skills seem to increase with an increase in years at work, in which the group with more than 11 years of experience responded more with $66.72 \%$. Most of the farmers here have education from lower secondary school and above and are not illiterate.

Table 2. Demographic characteristics (Source: According to the author's survey, 2020)

\begin{tabular}{|l|l|l|}
\hline Characteristics & \multicolumn{2}{|l|}{ Percent of frequency } \\
\hline $\mathbf{1 . \quad \text { Age }}$ & $\mathbf{N = 5 6 8}$ & $\mathbf{1 0 0 \%}$ \\
\hline $20-29$ years & 261 & 45.95 \\
\hline $30-39$ years & 104 & 18.31 \\
\hline $40-49$ years & 203 & 35.74 \\
\hline $\mathbf{2 . \quad \text { Sex }}$ & $\mathbf{N = 5 6 8}$ & $\mathbf{1 0 0 \%}$ \\
\hline Female & 389 & 68.49 \\
\hline Male & 179 & 31.51 \\
\hline $\mathbf{3 .} \quad$ Experience & $\mathbf{N = 5 6 8}$ & $\mathbf{1 0 0 \%}$ \\
\hline Less than 5 years & 74 & 13.03 \\
\hline $5-$ 10 years & 115 & 20.25 \\
\hline 11-16 years & 255 & 44.89 \\
\hline Over 16 years & 124 & 21.83 \\
\hline 4. Academic level & $\mathbf{N = 5 6 8}$ & $\mathbf{1 0 0 \%}$ \\
\hline Primary school graduated & 49 & 8.62 \\
\hline Secondary school graduated & 308 & 54.23 \\
\hline High school graduated & 186 & 32.75 \\
\hline College and University graduated & 25 & 4.40 \\
\hline
\end{tabular}

\section{Binary Logistic Regression Results}

2.1 Analysis of tests

a) Verification of the regression coefficient

The regression results with 7 initial independent variables showed that, Sig $(\mathrm{EXP})=0.818>0.1$ and $\mathrm{Sig}(\mathrm{NOE})=$ $0.213>0.1$, so the two variables of experience (EXP) and number of employs (NOE) are not statistically significant. Statistics or not affect the decision on application of high technology in agricultural production (DAHT). The remaining variables are education, participated in a social organization, capital, urbanization and market, with Sig values of 0.003 , $0.016,0.004,0.032,0.000<0.05$ respectively, so it is statistically significant and influential to decide to apply high technology in agricultural production (DAHT). After eliminating two experience variable (EXP) and number of employs variable (NOE), Binary Logistic was performed with SPSS 20, and obtained the following results:

From the results of the above regression analysis, we can see that the significance level Sig of the variables has the value $<0.05$, so the independent variables in the Binary Logistic regression model correlated with the dependent variable is decision to apply high technology in agricultural production (DAHT).

b) Verification of the suitability of the model

Verify the forecast accuracy of the model: The results in Table 4 show that there are 236 observing cases of not applying high technology in agricultural production, predicting there are 224 cases of not applying high technology in agricultural production and the prediction rate is correct. 94.92\%. There are 332 observational cases with high technology application in agricultural production, predicting there are 287 cases of high technology application in agricultural production with the correct prediction rate of $86.45 \%$. Hence, the correct prediction rate of the whole model is $92.08 \%$.

Check the suitability of the model: Based on the results of the Omnibus test on the suitability of the model in Table 5, we have Chi-square $=211.385$ and $\mathrm{Sig}=0.000<0.05$, so the independent variables have a linear relationship with dependent variable in the population. The model is suitable.

In Table 6, using the results of the regression coefficient column (B) and column Exp (B), form a scenario where the probability changes when the initial probabilities are $10 \%, 20 \%$, and $30 \%$, respectively $40 \%$ and $50 \%$. The results are as follows:

Variable CAP: Assuming the probability of applying technology of the original farmer is $10 \%$. When other factors do not change, if a household has a loan, the probability of this household's high-tech application will increase to $81.3 \%$. 
Similarly, 90.72\%, 94.37\%, 96.31\%, 97.51\% respectively when the initial probabilities are $20 \%, 30 \%$, 40\% and 50\%. This result shows that the capital variable has a positive impact on the decision to apply high technology in agricultural production, with results consistent with the study (Kinyangi, 2012; Baffoe-Asare et al., 2013; Son and Thanh, 2014). If farmers are supported with loans, they will have the opportunity to invest in modern equipment and machinery in agricultural production. This investment in the long term will help farmers save costs such as labor costs, mechanized hiring costs, etc. thereby helping farmers increase profits in production.

\subsection{Discussion on regression} results

Calculate and simulate the probability of applying high technology in agricultural production by the following formula:

$$
\mathrm{P}_{1}=\frac{\text { Poxe }^{\beta^{3}}}{1-\mathrm{Pop}_{1-e^{P_{j}}}}
$$

Where: $\mathrm{P} 0$ is the initial probability;

Table 6. Simulate probability of applying high technology in agricultural production (Source: According to the author's survey, 2020)

P1 is the change probability

Variable PSO: Assuming the probability of applying technology of the household is initially $10 \%$. When other factors do not change, if a household participates in social organization, the probability of applying high technology of this household will increase to $61.16 \%$, Similarly, $77.99 \%, 85.86 \%, 90.43$ respectively. $\%$, 93.41\% when the initial probabilities are $20 \%, 30 \%, 40 \%$ and $50 \%$. This result shows that the participation in social organization variable has a positive impact on the household head's decision to apply high technology in agricultural production, with consistent results (Son and Thanh, 2014; Kinyangi, 2012). That's right, because through social organizations, farmers are exposed to different strata in society, helping people to expand their knowledge, helping them realize the progress of science. reporting by participating in training courses, propaganda and seminars of social organizations. From there, it helps people to change perceptions and give up outdated farming habits.

Variable EDU: Assuming that the probability of applying technology of the household is $10 \%$ initially. When other factors do not change, if the number of years of schooling of the household head increases by one unit, the probability of applying high technology of this household will increase to $33.39 \%$. Similarly, 53\%, 65.91\%, 75.05\%, 81.85\% respectively when the initial probabilities are 20\%,30\%, 40\% and 50\%. This result shows that the education variable has a positive impact on the household head's decision to apply high technology in agricultural production, with results corresponding to the study (Kinyangi, 2012; Li et al., 2019; Baffoe-Asare et al., 2013). This is very true in fact, when the education level of the household head is higher, the ability to grasp high-tech equipment is higher than that of those with low education. Therefore, it has increased the ability to decide on the application of high technology in agricultural production.

Variable URB: Assuming the probability of applying technology of the original farmer is $10 \%$. When other factors do not change, if the impact of urbanization increases by one unit, the probability of high technology application of this household will increase to $54.55 \%$, Similarly, $72.97 \%, 82.24 \%, 87.81 \%, 91.23 \%$ respectively when the initial probabilities are $20 \%, 30 \%, 40 \%$, and $50 \%$. This result shows that urbanization variable has a positive impact on the decision to apply high technology in agricultural production. Urbanization has a significant impact on agricultural production, such as reducing arable land area, and reducing productivity. This motivates farmers to apply high technology to production to increase productivity and quality to meet market demand. Not only that, but urbanization also helps farmers to easily absorb technological advances, helping people no longer fall out of date in production (Anh, 2012).

Variable MAR: Assuming that the probability of applying technology of the household is initially $10 \%$. When other factors do not change, if availability of market increases by one unit, the probability of this household's high technology application will increase to $41.1 \%$. Similarly, 61.09\%, 72.91\%, 80.72\%, 86.27\% respectively when the initial probabilities are $20 \%, 30 \%, 40 \%$, and $50 \%$. This result shows that the availability of market variable positively influences the decision to apply high technology in agricultural production, this result corresponds to the study (Kinyangi, 2012). When markets are available, agricultural products are consumed quickly, and farmers have more incentive to produce. Because if there is no market for consumption, the leftover goods cause great damage to farmers because most agricultural products have a very short shelf life. Thus, revenue will decrease and farmers do not have money to pay for and invest in the next crop, so the application of technology will also decrease.

\section{CONCLUSION}

The research has built up a model of factors affecting the decision to apply high technology in agricultural production of farmers in the RRD. Based on the results of the Binary Logistic regression analysis and tests, it can be confirmed that the factors have affected the high technology application of the farmers include the farmer's education, participation in the social organization, the impact of urbanization, capital and availability of market is positive. The results of this study show that policies should be focused on enhancing the application of high technology, including establish appropriate policies to encourage households to borrow capital to invest in agricultural production. At the same time, the authorities strengthened the direction of the banking system to step in so that farmers could easily and conveniently access loans.

There are appropriate plans to quickly implement the work of land consolidation and exchange, on that side, do well the planning of fields, irrigation, and intra-field traffic to meet the requirements of synchronous mechanization. 
Increase funding for training for technical staff, households, farm owners, agricultural enterprises on skills in operating and maintaining agricultural machinery and equipment. Implementation of agricultural planning, regional planning and regional linkage in the direction of promoting local comparative advantages, and based on domestic and international market demand, should not be fixed area of rice, so conservation of agricultural land.

Enhance the role of social organizations such as the Farmers' Union, Women's Union, Youth Union and the Vietnam Consumers Association in encouraging the application of high technology in agricultural production and replication of examples, as well as promoting the link between farmers and enterprises in the chain of production, breeding and consumption of products. Although the initial research objectives have been set, the research still has certain limitations. Firstly, the survey was only conducted in 3 provinces of Nam Dinh, Thai Binh and Hai Duong, so the scope of research is limited. Secondly, the number of respondents who are female respondents is higher than that of men, gender equality among the respondents to this study is not achieved, so the representative of respondents may be limited. The next research direction for these studies is to compare the differences in the efficiency of agricultural production by the households using high technology and the group that does not use high technology in agricultural production.

\section{REFERENCES}

Anh, D.D. (2012). Research and development of hi-tech agriculture in Can Tho city. Master of Geography Thesis, Ho Chi Minh University of Education, Vietnam.

Baffoe-Asare, R., Danquah, J., \& Annor-Frempong, F. (2013). Socioeconomic factors influencing adoption of CODAPEC and cocoa hightech technologies among small holder farmers in Central Region of Ghana. American Journal of Experimental Agriculture, 3, $277-292$. https://doi.org/10.9734/AJEA/2013/1969

Biwas, B.C. (2010). Fertigation in high tech agriculture: A success story of a lady farmer. Fertiliser Marketing News, 41, 4-8.

Bucci, G., Bentivoglio, D., \& Finco, A. (2019). Factors affecting IT application in agriculture: A case study in Italy. Quality-Access to Success, 20, 122-129. https://www.researchgate.net/publication/332753855

Dang, N.M., Babel, M.S., \& Luong. H.T. (2011). Evaluation of food risk parameters in the day river flood diversion area, Red river delta, Vietnam. Natural Hazards, 56, 169-194. https://doi.org/10.1007/s11069-010-9558-x

Eneji, M.A., Weiping, S., \& Ushie, O.S. (2012). Benefits of agricultural technology innovation capacity to peasant farmers in rural poor areas: The case of DBN-Group, China. International Journal of Development and Sustainability, 1, 145-170. http://isdsnet.com/ijds

Gregorioa, G.B. \& Ancog, R.C. (2020). Assessing the impact of the Covid-19 pandemic on agricultural production in Southeast Asia: Toward transformative change in agricultural food systems. Asian Journal of Agriculture and Development, 17, 1-13.

Ha, N.T. (2019). HTA development in Soc Son district, Hanoi city. Master Thesis in Political Economy, VNU University of Economics \& Business, Vietnam.

John, I. (1996). Sustainable agriculture: A positive alternative to industrial agriculture. Heartland Roundup conference, Manhattan, Kansas, USA.

Kinyangi, A.A. (2012). Factors influencing the adoption of agricultural technology among smallholder farmers in Kakamega North subcounty, Kenya. Research project submitted in partial fulfillment of the requirements for the award of the degree of Master of arts in project planning and management of the University of Nairobi.

Lohmar, B., Gale, H., Frederick, Jr., Tuan, F.C., \& Hansen, J.M. (2009). China's ongoing agricultural modernization: Challenges Remain After 30 Years of Reform. Economic Information Bulletin, 51, U.S. Department of Agriculture, Economic Research Service.

Luu, T.A., Nguyen, A.T., Trinh, Q.A., Pham, V.T., Le, B.B., Nguyen, D.T., \& Hens, L. (2019). Farmers' Intention to Climate Change Adaptation in Agriculture in the Red River Delta Biosphere Reserve (Vietnam): A Combination of Structural Equation Modeling (SEM) and Protection Motivation Theory (PMT). Sustainability, 11, 2993. https://doi.org/10.3390/su11102993

Mien, N.T. (2018). Agricultural development with high technology barriers and solutions. Institute of Economics, Ho Chi Minh National Academy of Politics, Vietnam.

Phuong, T.T.M. \& Hien, N.T.M. (2014). Factors affecting the ability to have non-farm jobs in rural Hanoi city. Journal of Science and Development, 3, 829-835 (in Vietnamese).

Son, H.V \& Thanh, D.N, (2014). Factors affecting the application of technical advances in rice production by farmers in Hau Giang province. Journal of Can Tho University, 17, 85-93 (in Vietnamese).

Thien, N.C. \& Hanh, H.H. (2019). Solutions to develop high - tech agriculture in Vietnam at present. Socio-economic and environmental issues in development, 170, 154-165 (in Vietnamese).

Tri, N.M. (2021). Circular economic development ensures sustainable development in Vietnam: Opportunities and challenges. International Journal of Aquatic Science, 12, 2419-2430.

Wei, L., Wei, X., Zhu, R., \& Guo, K. (2019). Study of factors affecting the level of agricultural mechanization in China based on structural equation model. Sustainability, 11, 51. https://doi.org/10.3390/su11010051

Wolf, M. \& Terrell, D. (2016). The high-tech industry: What is it and why it matters to our economic future. Beyond the Numbers: Employment and Unemployment, 5(8), 1-7.

Xo, D.H \& Nhuong, P.H. (2006). High-tech agricultural development in Vietnam. Da Lat - Lam Dong Agriculture and Technology Extension Forum (in Vietnamese).

\footnotetext{
Article history: Received: 25.07.2021 Revised: 19.11.2021 Accepted: 15.12.2021 Available online: 31.12 .2021
} 